\title{
PENGARUH PENERAPAN TATA KELOLA, RASIO LIKUIDITAS, DAN TINGKAT EFISIENSI TERHADAP NILAI PERUSAHAAN DENGAN KINERJA KEUANGAN SEBAGAI VARIABEL INTERVENING PADA PERUSAHAAN PERBANKAN DI BEI
}

\author{
Bella Martina Wardani, Sunu Priyawan, Slamet Riyadi \\ Fakultas Ekonomi, Magister Manajemen 48 \\ Universitas 17 Agustus 1945 Surabaya, Indonesia \\ bellapunya.bm@gmail.com
}

\begin{abstract}
This study aims to analyze the influence of Corporate Governance, liquidity ratios and efficiency levels on financial performance and company value that can be used as a reference for management in using good and appropriate governance so that it can benefit the company as a whole. The population in this study uses all banking companies listed on the Indonesia Stock Exchange with a sample of 21 companies. The variables used in this study are Corporate Governance that is proxied by the Board of Commissioners, Independent Board of Commissioners, Board of Directors and Audit Committee, Liquidity Ratios that use the proxy Current Ratio, Quick Ratio and Cash Ratio, Efficiency Levels that use Operational Cost-Operational Proxies, Financial Performance that uses the proxy of Return On Assets (ROA), Return On Equity (ROE) and Net Profit Margin (NPM), while the company value uses Price to Book Value (PBV), Price Earning Ratio (PER) and TOBIN'S. using Smart PLS (Partial Least Square) analysis tool to determine the effect of these variables. The results of this study indicate that Corporate Governance has a significant negative effect on Financial Performance and Corporate Values, Liquidity Ratios and Efficiency Levels have a significant positive effect on Financial Performance and Corporate Value While Financial Performance has a significant negative effect on Firm Value.
\end{abstract}

\section{Keywords: Corporate Governance, Liquidity Ratio, EFFICIENCY Level, Financial Performance and Company Value}

\section{PENDAHULUAN}

Dunia perbankan di Indonesia memasuki masa persaingan yang kompetitif, Hal ini disebabkan banyaknya bank yang beroperasi di Indonesia baik bank-bank swasta dan pemerintah dalam negeri maupun bank-bank asing/luar negeri. Perkembangan perbankan yang cukup pesat serta tingkat kompleks usaha perbankan yang tinggi sangat berpengaruh pada nilai perusahaan. Dimana nilai perusahaan yang tinggi merupakan tujuan jangka panjang yang dicapai oleh perbankan yang akan tercermin dari harga sahamnya.

Pihak manajemen (agent) lebih mementingkan kepentingan pribadi (berusaha mendapatkan gaji tinggi) yang tidak sesuai tujuan perusahaan yaitu memakmurkan pemegang saham dan meningkatkan nilai perusahaan. Perlakuan manajer ini mengakibatkan penambahan biaya dalam perusahaan yang dapat mempengaruhi nilai perusahaan. 
Munculnya konflik perbedaan tujuan serta kepentingan antara manajer dan pemegang saham inilah yang pada akhirnya akan mendorong perlunya diterapkan di dalam perusahaan yaitu tata kelola yang baik (Good Corporate governancel GCG). GCG diharap mampu mengusahakan keseimbangan antara berbagai kepentingan dan akan memberikan keuntungan bagi perusahaan.

GCG merupakan sistem yang mengatur serta mengendalikan perusahaan dan menciptakan nilai tambah (value added). Penerapan konsep bahwa perusahaan harus melakukan pengungkapan (disclosure) secara akurat, tepat waktu, serta transparan terhadap informasi yang berkaitan dengan kepemilikan perusahaan dan stakeholder yang terlibat di dalam perusahaan.

Indonesia harus menerapkan pengawasan terhadap perusahaan pada sektor keuangan. Hal ini dimaksudkan agar Indonesia mempunyai sistem keuangan yang sehat secara fundamental dan berkesinambungan Otoritas Jasa Keuangan (2014).

\section{Rumusan Masalah}

Berdasarkan latar belakang di atas, penulis merumuskan permasalahan yang akan diteliti sebagai berikut :

1. Apakah tata kelola perusahaan berpengaruh signifikan terhadap kinerja keuangan perusahaan perbankan yang terdaftar di BEI ?

2. Apakah rasio likuiditas berpengaruh signifikan terhadap kinerja keuangan perusahaan perbankan yang terdaftar di BEI ?

3. Apakah efisiensi berpengaruh signifikan terhadap kinerja keuangan perusahaan perbankan yang terdaftar di BEI?
4. Apakah tata kelola perusahaan berpengaruh signifikan terhadap nilai perusahaan perbankan yang terdaftar di BEI?

5. Apakah rasio likuiditas berpengaruh signifikan terhadap nilai perusahaan perbankan yang terdaftar di BEI?

6. Apakah efisiensi berpengaruh signifikan terhadap nilai perusahaan perbankan yang terdaftar di BEI ?

7. Apakah kinerja keuangan berpengaruh signifikan terhadap nilai perusahaan perbankan yang terdaftar di BEI?

\section{KAJIAN PUSTAKA}

\section{Manajemen keuangan}

Manajemen keuangan merupakan suatu kegiatan perencanaan, penganggaran, pemeriksaan, pengelolaan, pengendalian, pencarian dan penyimpanan dana yang dimiliki oleh organisasi atau perusahaan (Wikipedia, 2017).

\section{Corporate Governance}

Corporate Governance merupakan salah satu elemen kunci dalam meningkatkan efisiensi ekonomis, yang meliputi serangkaian hubungan antara manajemen perusahaan, dewan direksi, para pemegang saham dan stakeholder lainnya. (Sutedi, 2011:3).

\section{Rasio likuiditas}

Rasio likuiditas adalah kemampuan perusahaan untuk melunasi kewajiban jangka pendek tepat pada waktunya. Pengendalian yang cukup diperlikan untuk mempertahankan kegiatan dan kelancaran operasional perusahaan yang bertujuan untuk menghindari adanya tindakan penyelewengan atau penyalahgunaan oleh karyawan perusahaan (Sawir,2012). 


\section{Tingkat Efisiensi}

Tingkat Efisiensi merupakan hal penting dari ketiga pokok bahasan value for money. Efisiensi diukur dengan rasio antara output dengan input. Semakin besar output dibanding input, maka semakin tinggi tingkat efisiensi suatu organisasi (Mardiasmo, 2009 : 133).

\section{Kinerja keuangan}

Kinerja keuangan adalah suatu analisis yang dilakukan untuk melihat sejauh mana suatu perusahaan telah melaksanakan dengan menggunakan aturanaturan pelaksanaan keuangan secara baik dan benar. Seperti dengan membuat suatu laporan keuangan yang telah memenuhi standar dan ketentuan dalam Standar Akuntansi Keuangan (SAK) atau General Acepted Accounting Principle (GAAP), dan lainnya (Fahmi, 2013: 35).

\section{Nilai perusahaan}

Nilai perusahaan didefinisikan sebagai nilai pasar karena nilai perusahaan dapat memberikan kemakmuran pemegang saham secara maksimum apabila harga saham perusahaan meningkat. Berbagai kebijakan yang diambil oleh manajemen dalam upaya untuk meningkatkan nilai perusahaan melalui peningkatan kemakmuran pemilik dan para pemegang saham yang tercermin pada harga saham. (Bringham \& Houston, 2016 : 19).

\section{Kerangka Konseptual}

Berdasarkan latar belakang, masalah pokok dan tinjauan pustaka pada bab sebelumnya, penulis menyusun kerangka konseptual penelitian sebagaimana tertera pada gambar 3.1.

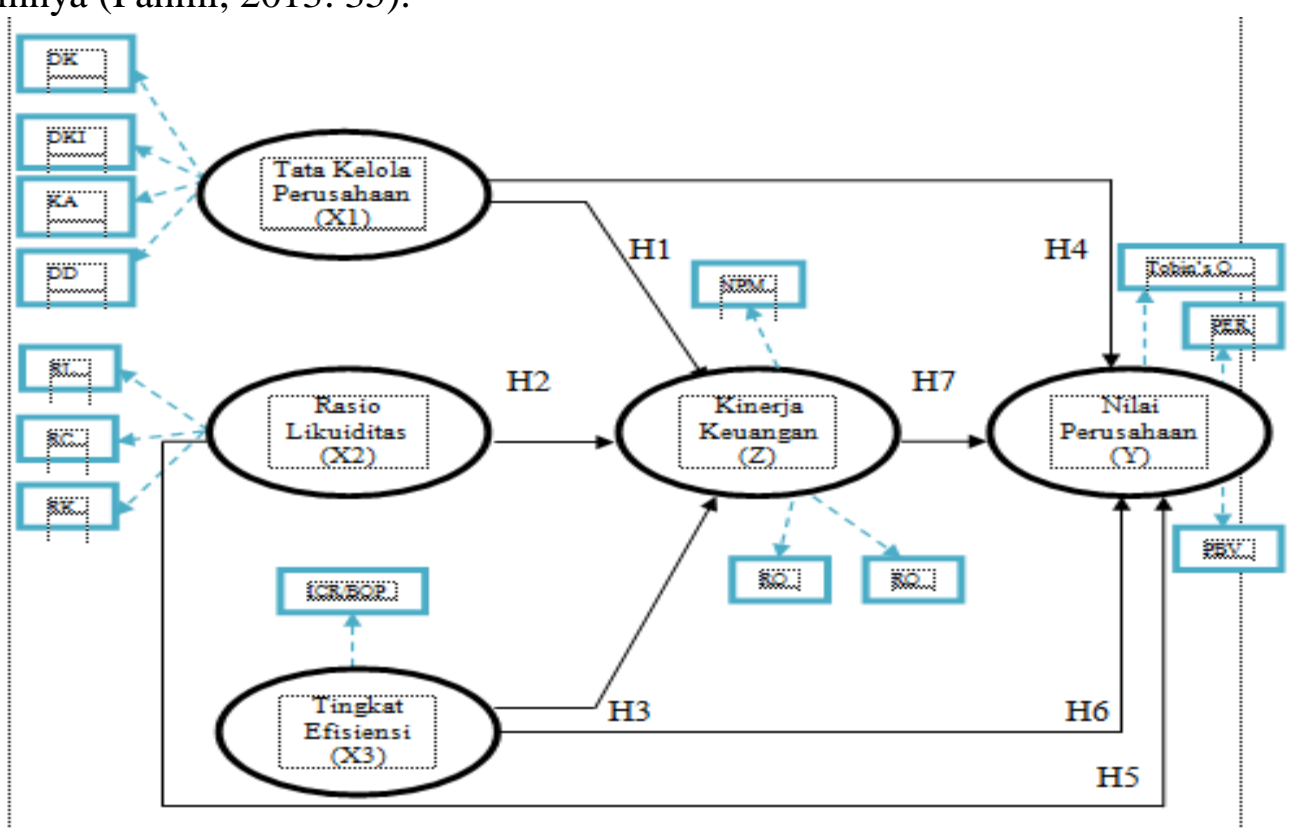

Gambar 3.1 Kerangka Konseptual beserta Indikator Empirik

Keterangan :

DK = Dewan Komisaris

ROA $=$ Return On Asset

DKI =Dewan Komisaris Independen

ROE = Return On Equity

$$
\begin{array}{ll}
\mathrm{DD} & =\text { Dewan Direksi } \\
\mathrm{ICR} & =\text { Income Cost Operating } \\
\mathrm{KA} & =\text { Komite Audit } \\
\mathrm{PER} & =\text { Price Earning Ratio } \\
\mathrm{RL} & =\text { Rasio Lancar }
\end{array}
$$




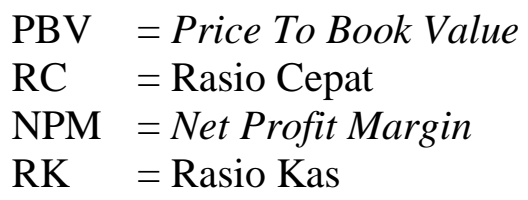

\section{Hipotesis}

Berdasarkan kerangka konseptual sebagaimana tertera pada gambar 3.1 penulis menetapkan hipotesis dalam penelitian sebagai berikut:

H.1. Tata kelola perusahaan berpengaruh signifikan terhadap kinerja keuangan perusahaan perbankan.

H.2. Rasio Likuiditas berpengaruh signifikan terhadap kinerja keuangan perusahaan perbankan.

H.3. Tingkat Efisiensi berpengaruh signifikan terhadap kinerja keuangan perusahaan perbankan.

H.4. Tata kelola perusahaan berpengaruh signifikan terhadap nilai perusahaan perbankan.

H.5. Rasio Likuiditas berpengaruh signifikan terhadap nilai perusahaan perbankan.

H.6. Tingkat Efisiensi berpengaruh signifikan terhadap nilai perusahaan perbankan.

H.7. Kinerja keuangan berpengaruh signifikan terhadap nilai perusahaan perbankan.

\section{METODE PENELITIAN}

Jenis penelitian menggunakan metode penelitian kuantitatif, dikatakan metode kuantitatif karena data penelitian berupa angka-angka dan analisis menggunakan statistik untuk menguji hipotesis (Sugiyono, 2017: 25).

\section{Populasi dan Sampel}

Populasi dalam penelitian ini adalah perusahaan perbankan yang listing yang tercatat di Bursa Efek Indonesia (BEI) periode 2015-2017 sejumlah 43 bank. Sampel penelitian ini sebanyak 21 bank yang listing di Bursa Efek Indonesia berturut-turut dari tahun 2015-2017.

\section{Metode analisis data}

Analisis data dalam penelitian ini menggunakan aplikasi program PLS Partial Least Square) versi 3.0 M3 PLS (Partial Least Square) dikembangkan pertama kali oleh wold sebagai metode umum untuk mengestimasi path model yang menggunakan konstruk laten dengan mutipe menggunakan mutipe indikator.

\section{HASIL PENELITIAN DAN ANALISIS}

Teknik analisis dalam penelitian ini menggunakan metode PLS (Partial Least Square). Di dalam PLS, terdapat dua bagian utama, yaitu measurement model (outer model) dan structural model (inner model). Outer model digunakan untuk menguji dan menganalisis validitas dan reliabilitas indikator pada setiap variabel, sedangkan inner model digunakan untuk menguji dan menganalisis hubungan kausalitas antar variabel. 
Tabel 5.12 Result For Outer Loading

\begin{tabular}{|c|c|c|c|c|}
\hline No. & Yariabel & Indikator & $\begin{array}{l}\text { Nilai } \\
\text { Outer } \\
\text { Loading }\end{array}$ & Keterangan \\
\hline \multirow{4}{*}{1.} & \multirow{4}{*}{$\begin{array}{l}\text { (X1) Tata Kelola } \\
\text { Perusahaan }\end{array}$} & $\begin{array}{l}\text { Audit } \\
\text { Commite }\end{array}$ & 0.320167 & TidakValid \\
\hline & & $\begin{array}{l}\text { Board of } \\
\text { Commissioners }\end{array}$ & 0.927511 & Valid \\
\hline & & $\begin{array}{l}\text { Board of } \\
\text { Director }\end{array}$ & 0.950241 & Valid \\
\hline & & $\begin{array}{l}\text { Independent } \\
\text { Commissioners }\end{array}$ & 0.689423 & Valid \\
\hline \multirow{3}{*}{2.} & \multirow{3}{*}{$\begin{array}{l}\text { (X2) Rasio } \\
\text { Likuiditas }\end{array}$} & Cash Ratio & 0.995554 & Valid \\
\hline & & Current Ratio & 0.995824 & Valid \\
\hline & & Quick ratio & -0.026197 & Tidak Valid \\
\hline 3. & $\begin{array}{l}\text { (X3) Tingkat } \\
\text { Efisiensi. }\end{array}$ & BOPO & 1.000000 & Valid \\
\hline \multirow{3}{*}{4.} & \multirow{3}{*}{$\begin{array}{l}\text { (Y) Nilai } \\
\text { Perusahaan }\end{array}$} & PBV & 0.883598 & Valid \\
\hline & & PER & 0.867816 & Valid \\
\hline & & Tobins'Q & 0.924604 & Valid \\
\hline \multirow{3}{*}{5.} & \multirow{3}{*}{$\begin{array}{l}\text { (Z) Kineria } \\
\text { Keuangan }\end{array}$} & NPM & 0.925216 & Valid \\
\hline & & ROA & 0.259214 & TidakValid \\
\hline & & $\mathrm{ROE}$ & 0.951513 & Valid \\
\hline
\end{tabular}

Berdasarkan evaluasi convergent validity diketahui ada 3 indikator pada variabel penelitian yang memiliki nilai outer loading lebih kecil dari 0,50 dan nilai T-statistics lebih kecil dari 1,96, yaitu Komite Audit, Quick Ratio dan Return On Asset sehingga ketiga

Tabel 5.13 Result For Outer Loading Dropping

\begin{tabular}{|c|c|c|c|c|}
\hline No. & Variabel & Indikator & $\begin{array}{c}\text { Nilai } \\
\text { Outer Loading }\end{array}$ & Keterangan \\
\hline \multirow{3}{*}{1.} & \multirow{3}{*}{$\begin{array}{l}\text { (X1) Tata } \\
\text { Kelola } \\
\text { Perusahaan }\end{array}$} & $\begin{array}{l}\text { Board of } \\
\text { Commissioners }\end{array}$ & 0.931358 & Valid \\
\hline & & $\begin{array}{l}\text { Board of } \\
\text { Director }\end{array}$ & 0.946168 & Valid \\
\hline & & $\begin{array}{l}\text { Independent } \\
\text { Commissioners }\end{array}$ & 0.702951 & Valid \\
\hline \multirow[t]{2}{*}{2.} & $\begin{array}{l}\text { (X2) Rasio } \\
\text { Likuiditas }\end{array}$ & Cash Ratio & 0.998986 & Valid \\
\hline & & Current Ratio & 0.998959 & Valid \\
\hline 3. & $\begin{array}{l}\text { (X3) Tingkat } \\
\text { Efisiensi. }\end{array}$ & $\mathrm{BOPO}$ & 1.000000 & Valid \\
\hline \multirow{3}{*}{4.} & \multirow{3}{*}{$\begin{array}{l}\text { (Y) Nilai } \\
\text { Perusahaan }\end{array}$} & PBV & 0.881466 & Valid \\
\hline & & PER & 0.870138 & Valid \\
\hline & & Tobins'Q & 0.925621 & Valid \\
\hline \multirow{2}{*}{5.} & \multirow{2}{*}{$\begin{array}{l}\text { (Z) Kinerja } \\
\text { Keuangan }\end{array}$} & NPM & 0.973286 & Valid \\
\hline & & ROE & 0.989411 & Valid \\
\hline
\end{tabular}

Berdasarkan evaluasi convergent validity tahap II diketahui semua indikator pada variabel penelitian sudah memiliki nilai outer loading lebih besar dari 0,50 dan nilai $\mathrm{T}$ statistics lebih besar dari 1,96, sehingga semua indikator tersebut disimpulkan valid dalam mengukur setiap variabel penelitian dan dan Kinerja Keuangan: indikator tersebut disimpulkan tidak valid dalam mengukur variabel yang diukur dan tidak memenuhi validitas konvergen (convergent validity) sehingga tidak dapat digunakan untuk analisis selanjutnya.

memenuhi validitas konvergen (convergent validity) sehingga dapat digunakan untuk analisis selanjutnya.

Berikut adalah hasil perhitungan composite reliability evaluasi outer model dropping pada variabel Tata Kelola Perusahaan, Rasio Likuiditas Tingkat efisiensi, Nilai Perusahaan 
Tabel 5.15 Composite Reliability

\begin{tabular}{|l|c|c|}
\hline \multicolumn{1}{|c|}{ Variabel } & $\begin{array}{c}\text { Composite Reliability } \\
\text { (Model Awal) }\end{array}$ & $\begin{array}{c}\text { Composite Reliability } \\
\text { (Eliminasi) }\end{array}$ \\
\hline $\begin{array}{l}\text { (X1) Tata Kelola } \\
\text { Perusahaan }\end{array}$ & 0.834033 & 0.899596 \\
\hline (X2) RasioLikuiditas & 0.791631 & 0.998972 \\
\hline (X3) Tingkat Efisiensi & 1.000000 & 1.000000 \\
\hline (Y) Nilai Perusahaan & 0.921355 & 0.921675 \\
\hline (Z) KineriaKeuangan & 0.795696 & 0.981207 \\
\hline \multicolumn{2}{|c|}{ Sumber. Data Sekunder Berdasarkan PLS 2.0,2019 } \\
\hline
\end{tabular}

Tabel di atas menunjukkan bahwa nilai composite reliability untuk semuaVariabel di atas 0,7 yang menunjukkan bahwa semua variabel pada model yang diestimasi mempunyai reliabilitas yang tinggi sehingga memenuhi criteria

\section{Analisis R-square}

Berdasarkan pengolahan data dengan PLS, dihasilkan nilai koefisien determinasi (R-square) sebagai berikut:

discriminant validity.

Tabel 516 R-Square

\begin{tabular}{|l|c|c|}
\hline \multicolumn{1}{|c|}{ Variabel } & $\begin{array}{c}\text { R Square } \\
\text { (Model Awal) }\end{array}$ & $\begin{array}{c}\text { R Square } \\
\text { (Eliminasi) }\end{array}$ \\
\hline (Y) Nilai Perusahaan & 0.103775 & 0.097950 \\
\hline (Z) KinerjaKeuangan & 0.012971 & 0.011403 \\
\hline
\end{tabular}

Sumber- Data Sekunder Berdasarkan PLS 2.0, 2019

Nilai $\mathrm{R}^{2}$ terletak antara $0-1$, dan kecocokan model dikatakan lebih baik kalau $\mathrm{R}^{2}$ semakin mendekati 1.Tabel $\mathrm{R}^{2}$ di atas memberikan :

a. Nilai 0.097950 untuk variabel(Y) Nilai Perusahaan yang berarti bahwa (X1) Tata Kelola Perusahaan, (X2) Rasio Likuiditas, (X3) Tingkat Efisiensi dan (Z) Kinerja Keuangan mampu dijelaskan(Y) Nilai Perusahaan sebesar $9.7 \%$ dan sisanya $90.3 \%$ tidak dijelaskan dalam penelitian ini disisi lainnya.

b. Nilai 0.011403 untuk variabel(Z) Kinerja Keuangan yang berarti
bahwa(X1) Tata Kelola

Perusahaan, (X2) Rasio Likuiditas dan (X3) Tingkat Efisiensi mampu dijelaskan (Z) Kinerja Keuangan sebesar $1.1 \%$ dan sisanya $98.9 \%$ tidak dijelaskan dalam penelitian ini disisi lainnya

Untuk membuktikan hipotesis yaitu dengan melihat signifikasi pengaruh antar variable dengan melihat koefisien parameter dan nilai signifikansi $\mathrm{t}$ statistic. Pada PLS2.0 hal tersebut dilakukan dengan melihat Algorithm Boostrapping report, berikut hasilnya : 


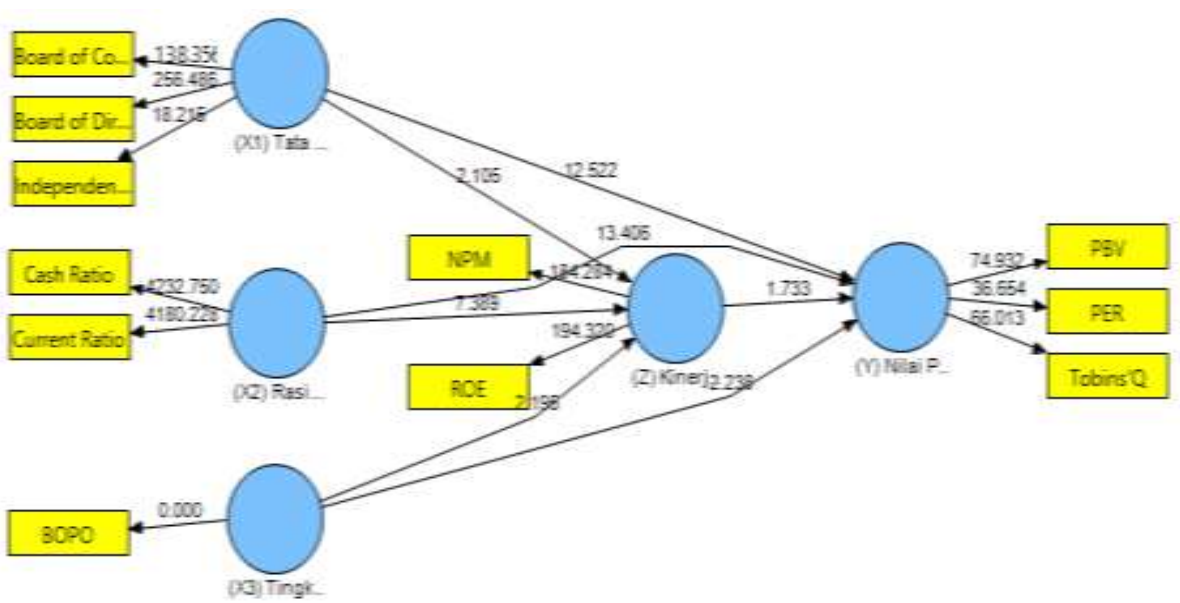

Gambar 51 Algorithm Boostrapping report

Tabel. 5.17 Algorithm Boostrapping report

\begin{tabular}{|c|c|c|c|c|c|c|}
\hline Variabel. & $\begin{array}{l}\text { Original } \\
\text { Sample } \\
\text { (O) }\end{array}$ & $\begin{array}{c}\text { Sample } \\
\text { Mean (AI) }\end{array}$ & $\begin{array}{l}\text { Standard } \\
\text { Deviation } \\
\text { (STDEV) }\end{array}$ & $\begin{array}{l}\text { Standard } \\
\text { Error } \\
\text { (STERR) }\end{array}$ & $\begin{array}{l}\text { T Statistics } \\
\text { (OO/STERR) }\end{array}$ & Keterangan \\
\hline $\begin{array}{l}\text { (X1) Tata Kelola } \\
\text { Perusahaen } \rightarrow(\mathrm{Y}) \\
\text { Dilai Perusahaen }\end{array}$ & -0.378662 & -0.383265 & 0.030240 & 0.030240 & 12.522041 & Signifikan \\
\hline $\begin{array}{l}\text { (X1) Tata Kelola } \\
\text { Peruaghaen } \rightarrow(\mathrm{Z}) \\
\text { KjnerjaKenangan }\end{array}$ & -0.067338 & -0.073066 & 0.031984 & 0.031984 & 2.105385 & Signifikan \\
\hline $\begin{array}{l}\text { (X2) } \\
\text { RasioLikuiditas } \rightarrow \\
\text { (Y) Nilai } \\
\text { Perusaham }\end{array}$ & 0.148761 & 0.151123 & 0.011097 & 0.011097 & 13.405538 & Signifikgn \\
\hline $\begin{array}{l}\text { (X2) } \\
\text { RasioLihuiditas -> } \\
\text { (Z) } \\
\text { KinejiaKeuangan }\end{array}$ & 0.089131 & 0.088540 & 0.012063 & 0.012063 & 7.388686 & Signifiksn \\
\hline $\begin{array}{l}\text { (X3) Tingkat } \\
\text { Efiasiensi- } \rightarrow(Y) \\
\text { Dijlai Perusahaen }\end{array}$ & 0.059194 & 0.062943 & 0.026446 & 0.026446 & 2.238281 & Signifikan \\
\hline $\begin{array}{l}\text { (X3) Tingkat } \\
\text { Efiaiengi - }>(Z) \\
\text { Kineriskepangm }\end{array}$ & 0.091802 & 0.100728 & 0.041815 & 0.041815 & 2.195430 & Signifikan \\
\hline $\begin{array}{l}\text { (Z) } \\
\text { KinejiaKeuangan - } \\
>(\mathrm{Y}) \text { Dilai } \\
\text { Perusahaen }\end{array}$ & -0.045045 & -0.039810 & 0.025988 & 0.025988 & 1.733274 & $\begin{array}{c}\text { Tidak } \\
\text { Signifikan }\end{array}$ \\
\hline
\end{tabular}

Sumber- Data Sekunder Berdasarkan PLS 2.0, 2019

\section{KESIMPULAN}

Berdasarkan hasil analisis dan pembahasan yang terdapat pada bab sebelumnya dalam penelitian ini, maka dapat diambil kesimpulan sebagai berikut :
1. Tata
Kelola
Perusahaan berpengaruh negative signifikan terhadap Kinerja Keuangan.
2. Rasio Likuiditas berpengaruh positif signifikan terhadap Kinerja Keuangan.

3. Tingkat Efisiensi berpengaruh positif signifikan terhadap Kinerja Keuangan.

4. Tata Kelola Perusahaan berpengaruh negative signifikan terhadap Nilai Perusahaan. 
5. Rasio Likuiditas berpengaruh positif signifikan terhadap Nilai Perusahaan.

6. Tingkat Efisiensi berpengaruh positif signifikan terhadap Nilai Perusahaan.

7. Kinerja Keuangan berpengaruh negative signifikan terhadap Nilai Perusahaan.

\section{DAFTAR PUSTAKA}

Agusti, Chalendra Prasetya. (2013)."Analisis Faktor Yang Mempengaruhi Kemungkinan Financial Distress Perusahaan Manufaktur Yang Terdaftar BEI Periode 2008-2011". Fakultas Ekonomi, Universitas Diponegoro

Deviacita, Arieany Widya. 2012. Analisis Pengaruh Mekanisme Corporate Governance terhadap Financial Distress

Ibadil, 2013 "Analisis Pengaruh Risiko, Tingkat Efisiensi, dan GCG terhadap Kinerja Keuangan Bank (Pendekatan Beberapa Komponen RBBR)" Universitas Diponegoro Semarang.

IICG. (2012). Corporate Governance Perception Index. (Website ww.iicg.org)

Ikatan Akuntan Indonesia. 2015. Pernyataan Standar Akuntansi Keuangan No.1. Jakarta:selemba empat

Irham, Fahmi. 2012. Analisis Laporan Keuangan. Bandung:Alfa Beta
Fery Ferial, Suhadak, Siti Ragil Handayani (2016) “ Pengaruh Good Corporate Governance Terhadap Kinerja Keuangan Dan Efeknya Terhadap Nilai Perusahaan (Studi Pada Badan Usaha Milik Negara Yang Terdaftar Di Bursa Efek Indonesia Periode 2012-2014) . Fakultas Ilmu Administrasi, Universitas Brawijaya Malang

Kasmir.2012. Bank dan Lembaga Keuangan Lainnya.Jakarta: Raja Grafindo Persada

Kasmir.2013. Analisis Laporan Keuangan, Cetakan Ke Enam Jakarata: Raja Grafindo Persada

Munawir S, S. 2004. Analisa Laporan Keuangan, Yogyakarta: Liberty.

Retno M, Reny Dyah dan Priantinah, Denies. (2012). Pengaruh Good Corporate Governance dan Pengungkapan Corporate Social Responsibility Terhadap Nilai Perusahaan (Studi Empiris Pada Perusahaan yang Terdaftar di Bursa Efek Indonesia Periode 2007-2010). Jurnal Nominal, Vol.1, No.1, hal 84-103

Mahendra DJ, Alfredo. (2011). Pengaruh Kinerja Keuangan Terhadap Nilai Perusahaan (Kebijakan Dividen Sebagai Variabel Moderating) Pada Perusahaan Manufaktur di Bursa Efek Indonesia). Thesis Program Magister Jurusan Manajemen Universitas Udayana Denpasar. 
Otoritas Jasa Keuangan. (2014). Roadmap Tata Kelola Perusahaan Indonesia Menuju Tata Kelola Emiten dan Perusahaan yang Lebih baik.

Peraturan Kementrian Badan Usaha Milik Negara KEP 117/MMBU/2002. Tentang Penerapan Praktek Good Corporate Governance pada Badan Usaha Milik Negara

Purwani, Tri. (2010). Pengaruh Good Corporate Governance Terhadap Kinerja Perusahaan. Majalah Ilmiah INFORMATIKA, Vol. 1, No.2, hal 47-60.
Sugiyono, 2010. Metode Penelitian Kuantitatif, Kualitatif, dan R\&D, Bandung:

Alfa Beta

Sutedi, Adrian. 2011. Good Corporate Governance, Jakarta: Sinar Grafika.

Tertius, Melia Agustina dan Christiawan, Yulius Jogi. (2015). Pengaruh Good Corporate Governance Terhadap Kinerja Perusahaan Pada Sektor Keuangan. Business Accounting Review, Vol. 3,No. 1, hal 223232 